Volume 6 Nomor 2, Agustus 2021, halaman 238 - 251.

\title{
Student Perceptions of Online Learning: Student Opinions and Expectations
}

\section{Persepsi Mahasiswa Terhadap Pembelajaran Secara Online: Pendapat dan Harapan Mahasiswa}

\author{
Denni Ismunandar ${ }^{1}$, Ardhin Primadewi ${ }^{2}$, Sofri Rizka Amalia ${ }^{3}$ \\ ${ }^{1}$ Prodi Pendidikan Matematika Universitas Wiralodra, denni.ismunandar@ unwir.ac.id \\ ${ }^{2}$ Prodi Teknik Informatika Universitas Muhammadiyah Magelang, ardhin@ummgl.ac.id \\ ${ }^{3}$ Prodi Pendidikan Matematika Universitas Peradaban sofri.rizkia@gmail.com
}

\begin{abstract}
ABSTRAK
Kasus Covid-19 berimbas pada dunia pendidikan. Salah satu imbasnya adalah pemerintah Indonesia menetapkan pembelajaran dilakukan melalui online. Namun kebijakan ini membebani mahasiswa dalam pembelajaran. Tujuan penelitian ini adalah mengetahui pendapat mahasiswa terkait dengan aplikasi online yang digunakan dan harapan mahasiswa dalam pembelajaran online. Penelitian ini menggunakan kuesioner menggunakan google form untuk mengetahui pendapat mahasiswa. Jumlah responden sebanyak 92 orang mahasiswa yang berasal dari beberapa perguruan tinggi. Data yang diperoleh dari kuesioner dianalisis secara manual, selanjutnya diseleksi dan dianalisis menggunakan software Atlas.ti untuk mendapatkan kesimpulan. Berbagai pendapat yang disampaikan oleh mahasiswa, salah satunya adalah kombinasi antara WhatsApp dan Elearning mudah diakses, mudah untuk digunakan, aman, dan cukup membantu mahasiswa memahami materi. Harapan mahasiswa pada pembelajaran online yaitu: dosen lebih memperhatikan kebutuhan mahasiswa terutama pada proses pembelajaraan dan pada proses evaluasi, selain itu pihak universitas diharapkan dapat mendukung pembelajaran secara online melalui bantuan kuota untuk membantu kelancaran proses pembelajaran.
\end{abstract}

Kata kunci: Perspektif Mahasiswa, Kuesioner, Harapan

\section{ABSTRACT}

The Covid-19 case has an impact on the world of education. One of the impacts is that the Indonesian government has determined that learning is carried out online. However, this policy burdens students in learning. The purpose of this study was to determine student opinions related to online applications used and student expectations in online learning. This study uses google form as a questionnaire to find out the opinions of students. The number of respondents was 92 students from several universities. The data obtained from the questionnaires were analyzed manually, then selected and analyzed using Atlas.ti software to obtain conclusions. Various opinions are expressed by students, one of which is the combination of WhatsApp and E-learning that is easy to access, easy to use, safe, and enough to help students understand the material. Students' expectations for online learning are lecturers pay more attention to student needs, especially in the learning process and in the evaluation process Besides that the university is expected to support online learning through quota assistance to help smooth the learning process.

Keyword(s): Student Perspective, Questionnaire, Expectations. 
How to Cite: Ismunandar, D., Primadewi, A., \& Amalia, S. R. (2021). Student Perceptions of Online Learning: Student Opinions and Expectations. Mathline: Jurnal Matematika dan Pendidikan Matematika, Vol. 6 No. 2, $238-251$.

DOI: https://doi.org/10.31943/mathline.v6i2.234

\section{PRELIMINARY}

In March 2020 there was a case of Corona Virus Disease -19 (Covid-19) in Indonesia. Corona virus is a highly contagious disease that causes epidemics of an acute respiratory syndrome. This epidemic turned into a global pandemic because until now more than 126,000 people died from Covid-19 (Dryhurst et al., 2020). Almost every country is struggling to reduce the spread of the Covid-19 virus by taking measures such as keeping their distance from others, washing their hands with water and soap, limiting their activity outside, and improving a sense of solidarity (Fisher et al., 2020). Covid-19 cases affect the lives of Indonesian people, both in the fields of health, economy, and education. Sintema's research in Zambia revealed the possibility of a decrease in the percentage of high school graduation results due to changes in the student academic calendar that were disrupted due to Covid-19 (Sintema, 2020). Specifically in Indonesia, the Minister of Education and Culture (Kemendikbud) issued a circular letter number 36962/MPK. A/HK/2020 about online learning and working from home. This circular forces all teaching and learning activities to be carried out from home. Specifically in Indonesia, the Minister of Education and Culture (Kemendikbud) issued a circular letter number 36962/MPK. $\mathrm{A} / \mathrm{HK} / 2020$ about online learning and working from home. This circular forces all teaching and learning activities to be carried out from home. Meanwhile, in the Philippines, the Philippine Commission for Higher Education has suspended face-to-face learning so that learning is carried out through distance learning through virtual learning since COVID-19 hit (Talidong et al., 2020).

In the implementation of online learning, learning activities that involve communication, question and answer discussions, and discussion of material will experience limitations (O'Leary, 2020). Several applications can be used in online learning, such as Google Classroom, Moodle, Zoom, Webex, WhatsApp, and many more. Applications that contain media in an educational context will have a profound impact on learning (Lu et al., 1999). The applications used can have an impact on students' abilities. Students who have a willingness to learn will try to find out and solve problems. 
However, in the implementation of learning, not all students in the same class have the same abilities depending on the group and students' basic knowledge (Scager et al., 2014). A person's capacity to solve problems varies in using his thoughts (Hürsen et al., 2014). In online learning, lecturers are less maximal in monitoring student development. In addition, lecturers do not give a maximum explanation to students (Hutauruk \& Sidabutar, 2020). Students also cannot interact directly with other students or with lecturers. The impact, students do not understand the material delivered by lecturers so that learning is less effective (Loviana \& Baskara, 2019; Prawanti \& Sumarni, 2020). Thus students need an online application that can help students in understand lecture materials during home learning.

Home learning with the right use of technology can potentially make the learning experience richer, more understanding, and more satisfying (Furlong \&Davies, 2012). Leat argues that online learning requires the ability of teachers to develop teaching strategies because it will affect students' understanding of the material (Livingston \& Condie, 2010). Online learning is carried out using software that has been agreed upon by lecturers and students, and it is best if the material to be discussed is given a few days in advance (Moorhouse, 2020). The use of applications in online learning that is currently being carried out will affect the level of student understanding, especially on the material being studied. Students during the Covid-19 pandemic can only be discussed online. Kleinhenz $\&$ Parker (2017) argues that using video can improve the understanding of student content. Game-based learning also results in advances in student knowledge (Turkay et al., 2014). Thus, a medium is needed in online learning to help students understand the material.

When the learning process is carried out from home, the ability to understand a concept in learning material is needed. Using the right learning methods when teaching students who are in a class with heterogeneous abilities will form talented students (Potts, 2019). According to Hunt, the course is not a problem, but the problem is that math teachers are unable to integrate courses into the mathematics curriculum (HernandezMartinez et al., 2011). The integration of courses into the curriculum will take a considerable amount of time but will develop students' ability to use and apply their mathematics. This will greatly improve students' understanding, but will also allow talented students the tools to develop their studies (Hernandez-Martinez et al., 2011). Delivery of the methods and tools needed in this pandemic requires the use of online applications that contain learning media. The media that will be used must be appropriate so that it can help students understand the material provided. 
In general, applications used in online learning there are slots or places to link a medium to help students understand the material provided (Brown et al., 2000). However, there are obstacles to the implementation of online learning (Henderikx et al., 2019). One such obstacle is that students have difficulty using learning tools or media (Viberg et al., 2020). Supporting online tools or media is invaluable for the smooth process of education in both school and higher education (Halkic \& Arnold, 2019; Song \& Bonk, 2016). Therefore, the media or applications used and the ability of teachers in teaching greatly affect the student's understanding of the material. In this study, researchers searched for learning conducted by lecturers during the pandemic. Researchers want to know how students think about learning conducted by lecturers and know the applications used by lecturers to support learning. This research needs to be done as input from lecturers to improve competence in developing learning based on input on the results of this research.

\section{METHODS}

The purpose of this research is to find out the applications used by students can learn, know the student's opinions on the learning conducted by lecturers, and know the expectations of students in online learning. In this study, participants took using accidental sampling techniques, namely the determination of samples by taking respondents who happened to exist. In this study, researchers asked for help from several lecturers to distribute questionnaires to students. Students were asked to fill out the questionnaire voluntarily, without coercion, and intimidation. This resulted in one class only a few students who filled out questionnaires in this study. Participants who filled out questionnaires in this study were as many as 92 students from several universities in Indonesia. Students who participated included Wiralodra University, Perabadan Bumiayu University, Muhammadiyah Magelang University, Pacitan State Community Academy, Cokroaminoto Palopo University, and Nusantara Islamic University. Participants who filled out this questionnaire were students who had been getting online learning for 2 semesters.

Researchers used questionnaires through Google forms that contained closed questions and open-ended questions. Closed questions using a Likert scale with a range between one to five and open questions have been discussed between researchers so that questionnaires given to students can be said to be logically valid. Closed questions consist of nine questions and open-ended questions consisting of five questions. 
Researchers used descriptive qualitative methods to describe the results of this study. Closed questions are described to determine the student's assessment of the online application used. While open questions are described to find out the student's opinion on learning conducted online. Filling out questionnaires to find out students' opinions is limited only to the learning process and applications used at the time of online learning. The questionnaire was conducted for five days, starting from May 19 to 23, 2020. Based on the data obtained, the data is grouped based on the applications used by students. Data is divided into two, namely data derived from closed questions and data from open questions. After the data is grouped, the results of closed question data are processed using Microsoft excel to find out the criteria using the Likert scale, while the results of open question data are processed using Atlas.ti software. The Likert scale used is as follows.

Table 1. Likert Scale (Çelik \& Laptalı Oral, 2016)

\begin{tabular}{ll}
\hline Score Interval & Evaluation Criteria \\
\hline $1,00-1,79$ & Very Low Level \\
$1,80-2,59$ & Low Level \\
$2,60-3,39$ & Medium Level \\
$3,40-4,19$ & High Level \\
$4,20-5,00$ & Very High Level \\
\hline
\end{tabular}

In this study, researchers used Table 1 as a classification of criteria and guidelines for the suspension of questionnaires that had been filled out by students on closed-door questionnaires. Furthermore, the results of open-ended questions that have been filled out by students are classified and separated into several documents based on the question number.

In Atlas.ti software, data is called a document. Documents that have been grouped in the selection. If there is the same meaning of the word, then it is only taken once but the number of words will continue to grow if there is the same meaning of the word. Based on these results are then created a network or net that can describe the results of the analysis based on the documents entered.

\section{RESULT AND DISCUSSION}

At the beginning of the discussion, the number of participants from students who have filled out the questionnaire is 92 people which in detail can be seen in Table 2. Next, 
the results of the questionnaires that have been filled out by students will be displayed in closed questions in Table 3.

Table 2. Distribution of questionnaire Filler Participants

\begin{tabular}{lcc}
\hline \multicolumn{1}{c}{ Name of College } & Departement & Sum of Students \\
\hline University Wiralodra & $\begin{array}{c}\text { Mathematics } \\
\text { Education }\end{array}$ & 17 \\
Muhammadiyah Magelang University & $\begin{array}{c}\text { Informatics } \\
\text { Engineering } \\
\text { Perabadan Bumiayu University }\end{array}$ & $\begin{array}{c}\text { Mathematics } \\
\text { Education } \\
\text { Mathematics } \\
\text { Cokroaminoto Palopo University }\end{array}$ \\
Nusantara Islamic University & $\begin{array}{c}\text { Mathematics } \\
\text { Education }\end{array}$ & 5 \\
Pacitan State Community Academy & $\begin{array}{c}\text { Informatics } \\
\text { Engineering }\end{array}$ & 12 \\
\hline
\end{tabular}

Table 2 is the number of students who fill out questionnaires given by lecturers. The results above illustrate that one class consisting of at least 10 students does not fill out questionnaires. Only a few students were willing to fill out questionnaires.

Table 3. Average Results of Student Satisfaction Suspension Of Online Applications

\begin{tabular}{|c|c|c|c|c|c|c|c|c|c|}
\hline No. & $\begin{array}{c}\text { Applications Used } \\
\text { in Learning }\end{array}$ & $\begin{array}{l}\text { Many } \\
\text { users }\end{array}$ & $\begin{array}{l}\text { Ease of } \\
\text { Access }\end{array}$ & $\begin{array}{c}\text { Ease of } \\
\text { downloading }\end{array}$ & $\begin{array}{c}\text { Ease of } \\
\text { uploading }\end{array}$ & $\begin{array}{c}\text { Ease of } \\
\text { navigation }\end{array}$ & $\begin{array}{l}\text { Level of } \\
\text { Security }\end{array}$ & $\begin{array}{l}\text { Level of } \\
\text { efficiency of } \\
\text { user and } \\
\text { application }\end{array}$ & $\begin{array}{c}\text { Understan } \\
\text { ding of } \\
\text { The } \\
\text { Material }\end{array}$ \\
\hline 1 & Google Classroom & 21 & 4,33 & 3,9 & 3,95 & 3,81 & 4,14 & 3,62 & 2,9 \\
\hline 2 & WhatsApp & 12 & 4,33 & 4,25 & 3,83 & 3,92 & 3,75 & 3,83 & 3,58 \\
\hline 3 & E-learning & 23 & 4,17 & 4,48 & 4,35 & 4,04 & 3,52 & 3,74 & 2,96 \\
\hline 4 & $\begin{array}{l}\text { Zoom Meeting } \\
\text { Kombinasi Google } \\
\text { Classroom and }\end{array}$ & 7 & 3,71 & 3,57 & 3,43 & 3,28 & 3,71 & 3,43 & 3,14 \\
\hline 5 & $\begin{array}{l}\text { WhatsApp } \\
\text { Kombinasi Zoom }\end{array}$ & 6 & 3,5 & 3,5 & 3,33 & 3 & 3,33 & 3,5 & 3,17 \\
\hline 6 & $\begin{array}{l}\text { and WhatsApp } \\
\text { Kombinasi } \\
\text { E-learning and }\end{array}$ & 8 & 4 & 4 & 4 & 3,75 & 3,13 & 3,13 & 3,13 \\
\hline 7 & $\begin{array}{l}\text { Cisco Webex } \\
\text { Kombinasi } \\
\text { WhatsApp and }\end{array}$ & 6 & 3,67 & 4 & 3,5 & 4 & 3,5 & 3,67 & 2,83 \\
\hline 8 & $\begin{array}{l}\text { E-learning } \\
\text { Jumlah }\end{array}$ & $\begin{array}{c}9 \\
92\end{array}$ & 4,67 & 4,67 & 4,67 & 4,22 & 4,11 & 4,22 & 3,67 \\
\hline
\end{tabular}

Table 3 can be seen that e-learning is used by 23 students. E-learning is a tool commonly used in supporting learning developed by each institution (Salema et al., 2021). E-learning is made by the institution, in this case, each college with the advantages and limitations of each college. E-learning is more widely used by students, meaning that the management of learning using this application managed by the institution is running well. 
Furthermore, Google Classroom is used by 21 students, WhatsApp is used by 12 students, and Zoom meeting is used by 7 students. In addition, the application can also be combined with other applications. In the application field used, it can be seen that WhatsApp is the most widely used application in online learning. WhatsApp becomes an application that is widely chosen by students because this application is often used in the daily life of students (Wijaya, 2018). This opinion is supported by Susilawati \& Supriyatno (2020), which state that most of the learning during the Covid-19 pandemic in Indonesia uses the WhatsApp application.

The highest average ease of access is the combination of E-learning with WhatsApp at 4.67, followed by the use of WhatsApp and Google Classroom with an average of 4.33. Student opinion on the ease of downloading material chooses a combination of E-learning and WhatsApp to be the largest average and the combination between Google Classroom and WhatsApp is an application that students are rated less. Based on the level of ease of students to upload work, Google Classroom and WhatsApp are the lowest average applications. The combination of E-learning and WhatsApp on the ease of finding navigation or work buttons gets the highest average, which is 4.22.

Furthermore, for the level of security, the Google Classroom application becomes the main choice of students, because to be able to access Google classroom need to enter the classroom by filling in a username and password first. The highest average efficiency rate is a combination of WhatsApp and E-learning applications, which is 4.22. Nevertheless, at the level of students' understanding of the given material, the combination of WhatsApp and E-learning only had an average of 3.67. This means that the combination of the use of this application has not been maximal to help students experience a material. However, the results of Barhoumi's research (2015) stated that WhatsApp is a good learning tool in the implementation of learning. Furthermore, the researchers limit will only discuss the opinions of students in using a combination of WhatsApp and E-learning applications. This is because the use of a combination of applications is considered by students to help students understand the material.

The first discussion will be displayed about the results of student opinions so that students can easily understand the material when using a combination of WhatsApp and Elearning applications. 


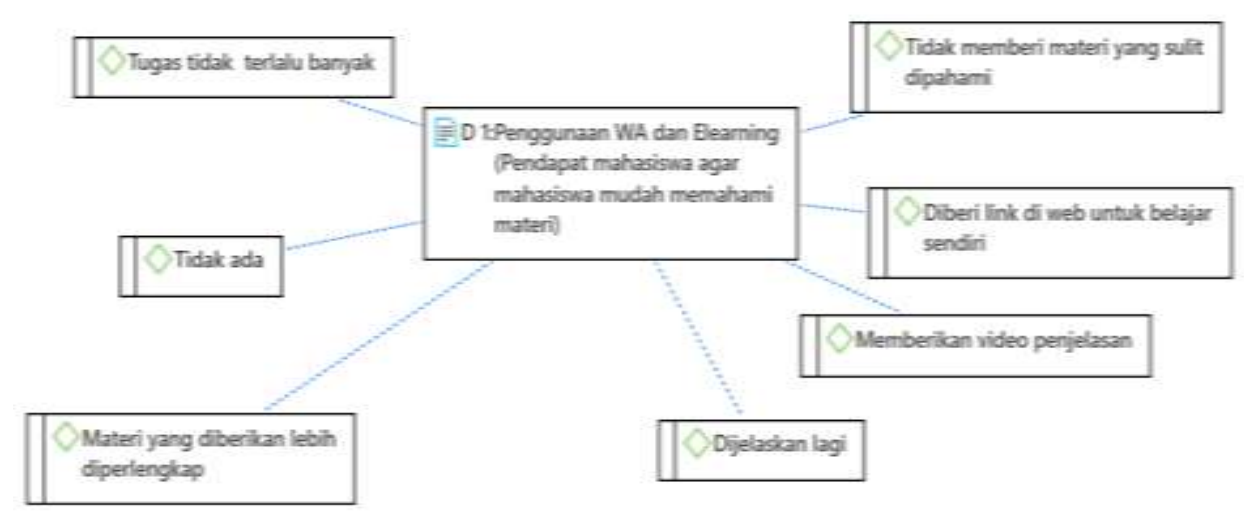

Figure 1. Student Opinion Results so that Students Easily Understand the Material In figure 1, some student opinions are: students ask to be explained again on the material that has been taught; lecturers can provide videos to clarify the material; providing a link of materials to be taught so that before learning students can learn first; the material submitted by the lecturer must be complete; And don't give away too much work. One of the students' opinions is not to give difficult material as one of the homework for lecturers so that lecturers provide material as clearly as possible so that students can understand the material. Furthermore, the results of student opinions will be presented about the methods implemented by lecturers in online learning.

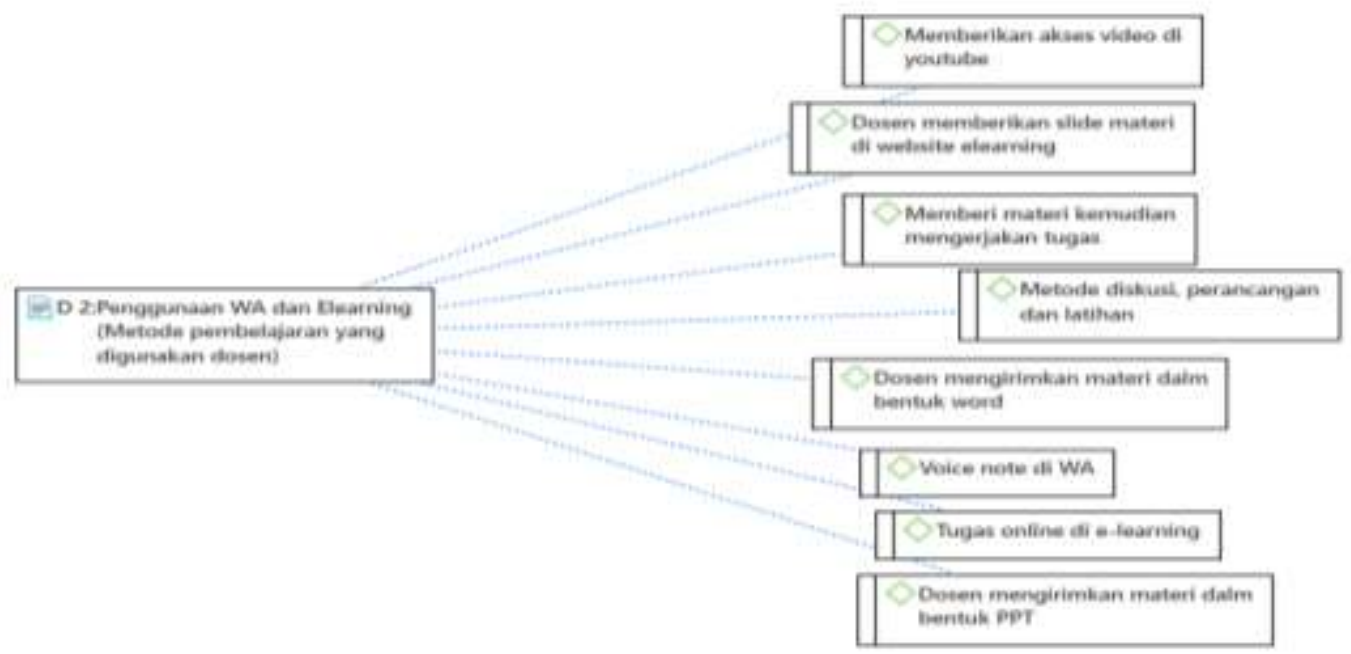

Figure 2. Methods Used by Lecturers During Online Learning

In Figure 2, the student's answer is more pointed to the implementation of learning. The results above show that lecturers use E-learning and WhatsApp to submit tasks and explain unlearned material using voice notes. The provision of material is done first, then discusses, and then the task is sent through E-learning. In figure 2 also shows that lecturers conduct discussions, designs, and exercises. Discussions can be done through WhatsApp calls, compounding can be done through chat on E-learning and chat on WhatsApp. While 
the training can be done in E-learning. The results of the student expectation analysis of the methods used by lecturers are shown in the following figure 3 .

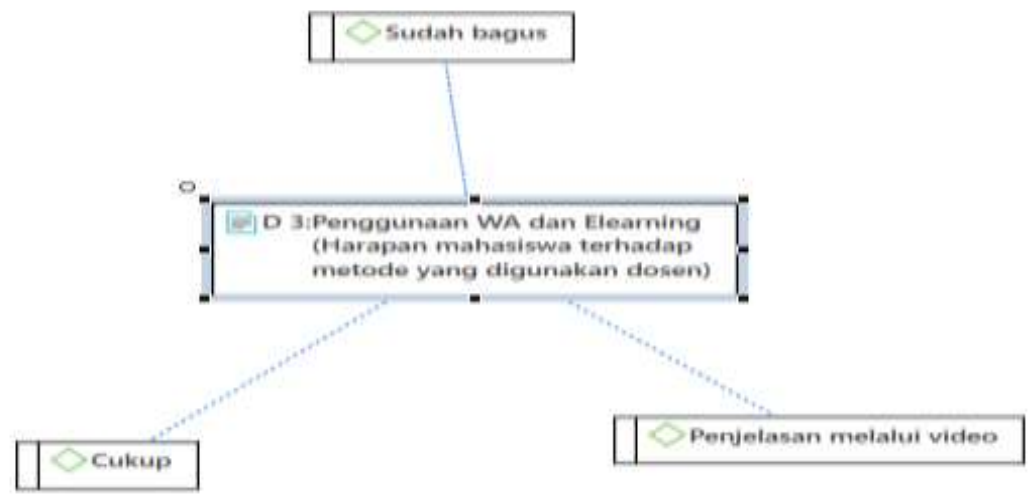

Figure 3. Results of Student Expectation Analysis of Methods Used by Lecturers

In figure 3, some input from students is the method used is good and sufficient. However, lecturers need to add explanations through video so that students understand the material by looking back at the video material that has been studied. The following will be shown the learning methods that students expect during the online learning period.

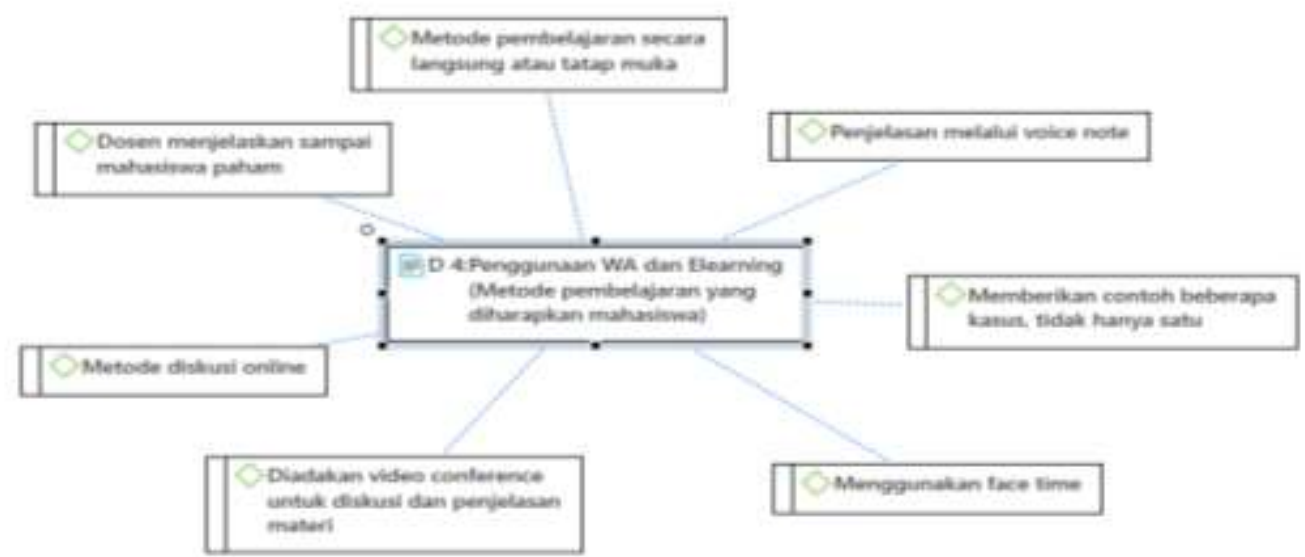

Figure 4. Learning Methods That Students Expect

The data in Figure 4 shows the willingness of students to be able to meet face-toface both online and offline. In addition, students expect the example given not only one so that students can better understand. Another opinion is that students want the lecturer to explain so that students understand the material. In this case, students can study together with friends who have a better level of understanding or try to find free time for lecturers to be able to ask questions that students do not understand. Next will be discussed student opinions so that online learning can be more effective. 


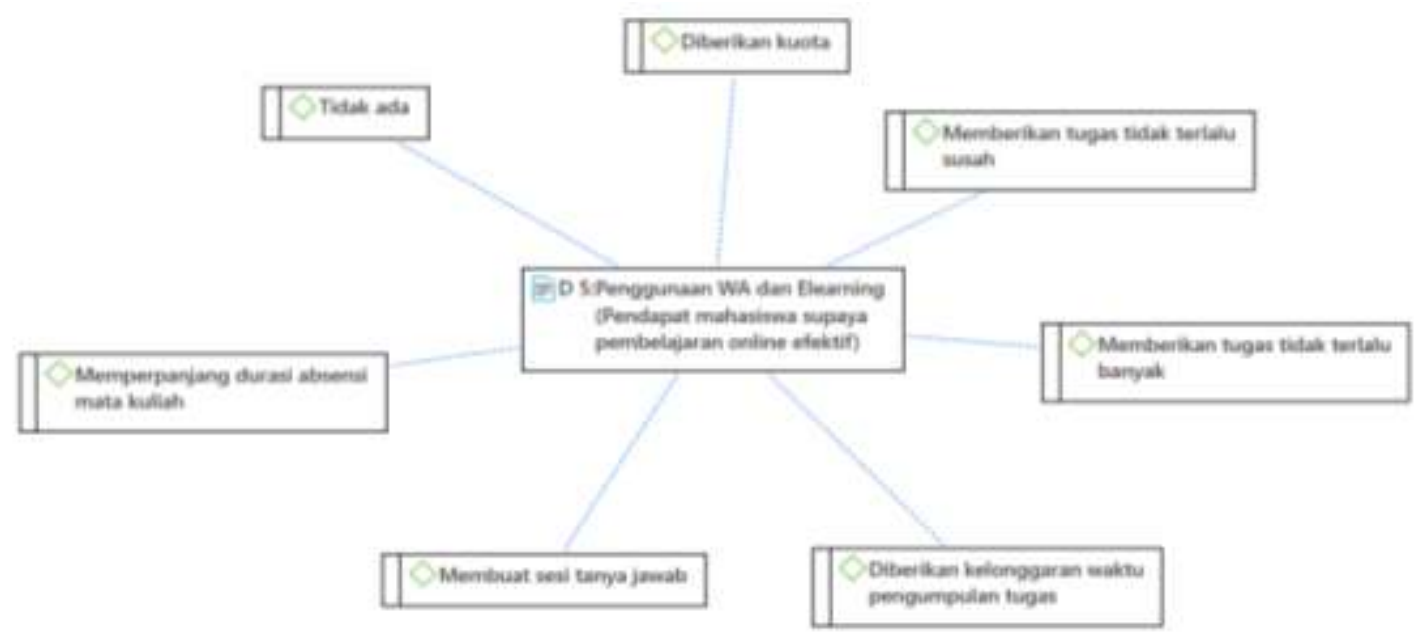

Figure 5. Student Opinions to Make Online Learning More Effective

Figure 5 shows that students still have difficulty getting data quotas to support the online teaching and learning process. The data quota obtained from the Ministry of Education and Culture is still lacking. This is possible because some lecturers use online face-to-face applications so that the data quota runs out faster. In addition, giving many and difficult assignments makes students less effective in participating in online learning. In addition, according to students, the question and answer session and the leeway in collecting assignments were factors that made learning effective.

The results of this study are in line with the results of Sartika's research (2018), that the use of WhatsApp is very helpful for students in the online learning process. In addition, Prajana et al., (2018) revealed that WhatsApp media can be collaborated with other learning support media to support learning. Similarly stated by Khasanah et al., (2021), that WhatsApp is effectively used for online learning.

\section{CONCLUSION}

Based on the opinion of the students above, online learning that has been done requires some improvements. Some of the things that students expect on learning in a way are: (1) The most widely used application is WhatsApp. In this study the combination between WhatsApp and E-Learning becomes a combination of applications that are considered more helpful to students in learning in the pandemic period, (2) Lecturers do not give too many tasks, (3) Lecturers can provide video explanations so that the material can be relearned, (4) The material sent by lecturers should be complete and detailed, (5) Lecturers hold face-to-face either in person or online, (6) Students hope from the university to provide quota assistance to help the smoothness of the learning process. The results of this 
research are expected to be considered by Mr / Mrs. Lecturer in teaching online and the college to help students carry out the learning process to be better.

\section{THANK-YOU NOTE}

Thank God for giving me health so that I can finish this article as well as possible. In addition, I also do not forget to thank those who have helped in the preparation of this article, either directly or indirectly. Lastly, I thank the journal manager for allowing me to publish my article in this journal.

\section{REFERENCES}

Barhoumi, C. (2015). The Effectiveness of WhatsApp Mobile Learning Activities Guided by Activty Theory on Students' Knowldege Management. Contemporary Educational Technology, 6(3), 221-238. https://doi.org/10.30935/cedtech/6151

Brown, S., Hardaker, C. H. M., \& Higgett, N. P. (2000). Designs on the Web: a case study of online learning for design students. Alt-J, 8(1), 30-40. https://doi.org/10.1080/0968776000080104

Çelik, G. T., \& Laptalı Oral, E. (2016). Big Five and Organizational Commitment-The Case of Turkish Construction Professionals. Human Resource Management Research, 6(1), 6-14. https://doi.org/10.5923/j.hrmr.20160601.02

Dryhurst, S., Schneider, C. R., Kerr, J., Freeman, A. L. J., Recchia, G., Bles, A. M. Van Der, Spiegelhalter, D., Dryhurst, S., Schneider, C. R., Kerr, J., Freeman, A. L. J., Recchia, G., Bles, A. M. Van Der, Spiegelhalter, D., \& Linden, S. Van Der. (2020). Risk perceptions of COVID-19 around the world. Journal of Risk Research, O(0), 113. https://doi.org/10.1080/13669877.2020.1758193

Fisher, J., Languilaire, J.-C., Lawthom, R., Nieuwenhuis, R., Petts, R. J., Runswick-Cole, K., \& Yerkes, M. A. (2020). Community, work, and family in times of COVID-19. Community, Work \& Family, 23(3 PG-247-252), 247-252. https://doi.org/10.1080/13668803.2020.1756568

Furlong, J., \& Davies, C. (2012). Young people, new technologies and learning at home: Taking context seriously. Oxford Review of Education, 38(1), 45-62. https://doi.org/10.1080/03054985.2011.577944

Halkic, B., \& Arnold, P. (2019). Refugees and online education: student perspectives on need and support in the context of (online) higher education. Learning, Media and Technology, 44(3), 345-364. https://doi.org/10.1080/17439884.2019.1640739 
Henderikx, M., Kreijns, K., Castaño Muñoz, J., \& Kalz, M. (2019). Factors influencing the pursuit of personal learning goals in MOOCs. Distance Education, 40(2), 187-204. https://doi.org/10.1080/01587919.2019.1600364

Hernandez-Martinez, P., Williams, J., Black, L., Davis, P., Pampaka, M., \& Wake, G. (2011). Mathematics coursework as facilitator of formative assessment, studentcentred activity and understanding. Research in Mathematics Education, 13(2), 197212. https://doi.org/10.1080/14794802.2011.585830

Hürsen, Ç., Kaplan, A., \& Özdal, H. (2014). Assessment of Creative Thinking Studies in Terms of Content Analysis. Procedia - Social and Behavioral Sciences, 143(2006), 1177-1185. https://doi.org/10.1016/j.sbspro.2014.07.574

Hutauruk, A., \& Sidabutar, R. (2020). Kendala pembelajaran daring selama masa pandemi di kalangan mahasiswa pendidikan matematika: Kajian kualiatatif deskriptif. Journal of Mathematics Education and Applied, 02(01), 45-51. https://jurnal.uhn.ac.id/index.php/sepren/article/view/364

Khasanah, K., Nasan, E., \& Jus'aini, J. (2021). Efektifitas Media WhatsApp Group Dalam Pembelajaran Daring. Akademika, 10(01), 47-65. https://doi.org/10.34005/akademika.v10i01.1344

Kleinhenz, P. N., \& Parker, M. S. (2017). Video as a tool to increase understanding and support for the Endangered Species Act. Applied Environmental Education and Communication, 16(1), 41-55. https://doi.org/10.1080/1533015X.2017.1282333

Livingston, K., \& Condie, R. (2010). The Impact of an Online Learning Program on Teaching and Learning Strategies. Theory Into Practice, 45(2), 150-158. https://doi.org/10.1207/s15430421tip4502

Loviana, S., \& Baskara, W. N. (2019). Dampak Pandemi Covid-19 Pada Kesiapan Pembelajaran Tadris Matematika Iain Metro Lampung. Epsilon, 1(2), 61-70. www.journal.uta45jakarta.ac.id

Lu, G., Wan, H., \& Liu, S. (1999). Hypermedia and its application in education. International Journal of Phytoremediation, 21(1), 41-45. https://doi.org/10.1080/0952398990360107

Moorhouse, B. L. (2020). Adaptations to a face-to-face initial teacher education course 'forced' online due to the COVID-19 pandemic. Journal of Education for Teaching, OO(00), 1-3. https://doi.org/10.1080/02607476.2020.1755205

O'Leary, D. E. (2020). Evolving Information Systems and Technology Research Issues for COVID-19 and Other Pandemics. Journal of Organizational Computing and 
Electronic Commerce, 00(00), 1-8. https://doi.org/10.1080/10919392.2020.1755790 Potts, J. A. (2019). Profoundly Gifted Students' Perceptions of Virtual Classrooms. Gifted Child Quarterly, 63(1), 58-80. https://doi.org/10.1177/0016986218801075

Prajana, A., Ilmiah, P., Fauzi, A. A. R., Studi, P., Komunikasi, I., Komunikasi, F., Informatika, D. A. N., Surakarta, U. M., Buchenscheit, A., Könings, B., Neubert, A., Schaub, F., Schneider, M., Kargl, F., Putri, N. E., Iskandar, D., Anwar, N., Riadi, I., Junaida, D. S., ... Zuliarso, E. (2018). Pemanfaatan Aplikasi Whatsapp dalam Media Pembelajaran di UIN Ar-Raniry Banda Aceh. Cyberspace: Jurnal Pendidikan Teknologi Informasi, 2(2), 3.

Prawanti, L. T., \& Sumarni, W. (2020). Kendala Pembelajaran Daring Selama Pandemic Covid-19. Prosiding Seminar Nasional Pascasarjana UNNES, 286-291.

Salema, N. E., Clement, N., Hysenagolli, R., Hibberd, R., Bell, B. G., Gookey, G., Avery, A., \& Knox, R. (2021). The evaluation of an e-learning prescribing course for general practice. Education for Primary Care, 32(4), 219-225. https://doi.org/10.1080/14739879.2021.1874250

Sartika, S. (2018). Kegunaan whatsapp sebagai media informasi dan media pembelajaran pada mahasiswa ilmu komunikasi STISIP persada bunda. Medium, 6(2), 15-26.

Scager, K., Akkerman, S. F., Pilot, A., \& Wubbels, T. (2014). Challenging high-ability students. Studies in Higher Education, 39(4), 659-679. https://doi.org/10.1080/03075079.2012.743117

Sintema, E. J. (2020). Effect of COVID-19 on the Performance of Grade 12 Students: Implications for STEM Education. Eurasia Journal of Mathematics, Science and Technology Education, 16(7), 1-6. https://doi.org/10.29333/ejmste/7893

Song, D., \& Bonk, C. J. (2016). Motivational factors in self-directed informal learning from online learning resources. Cogent Education, 3(1). https://doi.org/10.1080/2331186X.2016.1205838

Susilawati, S., \& Supriyatno, T. (2020). Online Learning Through WhatsApp Group in Improving Learning Motivation in the Era and Post Pandemic COVID -19. Jurnal Pendidikan, 5(6), 852-859.

Talidong, K. J. B., Toquero, C. M. D., Joy, K., Mae, C., \& Philippine, D. T. (2020). Philippine Teachers 'Practices to Deal with Anxiety amid COVID-19 Philippine Teachers ' Practices to Deal with Anxiety. Journal of Loss and Trauma, 0(0), 1-7. https://doi.org/10.1080/15325024.2020.1759225

Turkay, S., Hoffman, D., Kinzer, C. K., Chantes, P., \& Vicari, C. (2014). Toward 
Understanding the Potential of Games for Learning: Learning Theory, Game Design Characteristics, and Situating Video Games in Classrooms. Computers in the Schools, 31(1-2), 2-22. https://doi.org/10.1080/07380569.2014.890879

Viberg, O., Grönlund, Å., \& Andersson, A. (2020). Integrating digital technology in mathematics education: a Swedish case study. Interactive Learning Environments, O(0), 1-12. https://doi.org/10.1080/10494820.2020.1770801

Wijaya, A. (2018). Students ' Responses Toward the Use of Whatsapp in Learning. Journal of Teaching \& Learning English in Multicultural Contexts, 2(1), 46-55. 